\title{
Evaluasi Administrasi Kegiatan Bank Sampah Cawang Hijau Indah Ktut Silvanita Mangani
}

Universitas Kristen Indonesia, Jakarta, Indonesia

E-mail: ktut.silvanita@uki.ac.id

\begin{abstract}
Abstrak
Bank sampah Cawang Hijau Indah RW 06 didirikan sejak 16 September 2013. Pengurus Bank Sampah Cawang Indah melakukan kegiatannya secara rutin satu minggu sekali, dengan menerima beberapa bentuk sampah yang telah ditetapkan pada harga tertentu. Masyarakat yang memberikan/menjual sampahnya ke Bank Sampah tidak menerima uangnya secara tunai, tetapi dicatatkan oleh pengurus dalam Buku Tabungan Bank Sampah, serta dicatat dalam Buku Besar Pengurus. Kegiatan Pengabdian Kepada Masyarakat (PKM) Green Action ke-19, salah satunya adalah evaluasi terhadap administrasi kegiatan Bank Sampah Cawang Hijau RW 06, Kelurahan Cawang. Evaluasi dilakukan melalui wawancara terhadap pengurus dan dengan memperhatikan pembukuan yang dilakukan dalam kegiatan bank sampah. Berdasarkan hasil evaluasi, maka penulis menemukan beberapa kesulitan dalam pencatatan bank sampah, dan disarankan manajemen akuntansi organisasi Bank Sampah mengikuti aturan-aturan standar akuntansi sederhana dengan beberapa modifikasi sesuai dengan kondisi dan kebutuhan organisasi. Saran yang diberikan terkait Prinsip Tabungan dan Prinsip Pencatatan Kegiatan Bank Sampah, yang terdiri dari Pencatatan Buku Tabungan, Pencatatan Jurnal Harian, serta Pencatatan Buku Kas/Neraca Saldo.
\end{abstract}

Kata Kunci: Administrasi Bank sampah

\begin{abstract}
The Cawang Hijau Indah Waste Bank RW 06 was established on September 16, 2013. The management carries out its activities regularly once in a week, by receiving/buying certain forms of waste at a given price. People who sell their things to the Waste Bank do not receive their money in cash but are recorded by the management in the Waste Bank Savings Book, as well as being recorded in the Management Ledger. The 19th Green Action Community Service (PKM) activity, one of which was an evaluation of the administration of the Cawang Hijau Waste Bank at RW 06 of Kelurahan Cawang. An evaluation was carried out through interviews with the management and by paying attention to the bookkeeping carried out in waste bank activities. The author found that there are several difficulties in recording the waste bank administration and recommended some solutions. The management of the waste bank shall follow the rules of simple accounting standards with some modifications according to the conditions and the needs of the organization. The advice given is related to the Savings Principle and the Principles of Recording Waste Bank Activities, which consist of Savings Book Recording, Daily Journal Recording, and Cash Book/Balance Sheet Recording.
\end{abstract}

Keywords:Waste Bank Administration

\section{PENDAHULUAN}

Lingkungan yang bersih dan asri

merupakan idaman semua orang.

Untuk menciptakan lingkungan yang berkualitas tidak terlepas dari

manusianya (Dwiyatmo, 2007). Masyarakat warga RT 06 Kelurahan Cawang menyadari, bahwa tumpukan sampah membuat lingkungan menjadi 
kotor dan dapat berdampak pada kesehatan. Oleh karena itu, warga RW 06 Kelurahan Cawang secara bergotong-royong berupaya untuk mendirikan bank sampah yang diberi nama Bank Sampah Cawang Hijau Indah, yang didirikan pada tanggal 16 September 2013.

Bank sampah adalah suatu tempat yang digunakan untuk mengumpulkan sampah yang sudah dipilah-pilah. Selanjutnya, sampah yang telah dipilah-pilah disetorkan ke tempat pengepul sampah atau dibuat kerajinan dari sampah (DLH Buleleng, 2020).

Namun, dalam perjalanannya kegiatan bank sampah ini mengalami jatuh bangun karena budaya memilah sampah yang belum terbangun. Masalah tersebut terkait dengan rendanya kesadaran pribadi, moralitas dan hati nurani (Hardin, 1982). Namun, dengan bantuan program Pengabdian Kepada Masyarakat Green Action yang diinisiasi oleh Fakultas Teknik UKI, akhirnya kegiatan Bank Sampah terus berjalan. Sampai akhirnya pada bulan Januari 2018 ditetapkan sebagai salah satu bank sampah yang aktif di Kelurahan Cawang baru dengan Surat Keputusan Lurah Cawang Nomor: 41/2018. Dalam surat keputusan tersebut, tercantum kepengurusan
Bank Sampah Cawang Hijau Indah, yang terdiri dari Ketua, Sekretaris, Bendahara, dan anggota (Gambar 1).

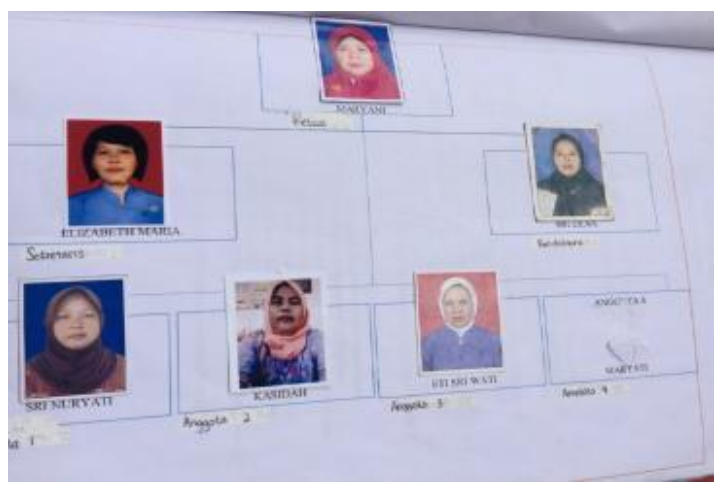

\section{Gambar 1. Pengurus Bank Sampah Cawang Hljau Indah \\ Sejak didirikan hingga sekarang,} Bank Sampah Cawang Hijau Indah RW 06 telah menunjukkan kemajuan. Hal itu ditunjukkan setoran sampah yang terus meningkat, dan Bank Sampah Cawang Hijau Indah RW 06 telah menjadi juara kelompok kegiatan Bank Sampah di Kelurahan Cawang dan menjadi perwakilan dalam kejuaraan tingkat wilayah Jakarta Timur.

Pengurus Bank Sampah Cawang Indah melakukan kegiatannya secara rutin satu minggu sekali, dengan menerima beberapa bentuk sampah yang telah ditetapkan pada harga tertentu yang ditetapkan oleh pengurus. Masyarakat yang memberikan/menjual sampahnya ke Bank Sampah tidak menerima uangnya secara tunai, tetapi dicatatkan oleh pengurus dalam Buku Tabungan Bank Sampah, selain dicatat dalam Buku Besar 
Pengurus. Manajemen UKI, salah satu kegiatannya adalah evaluasi terhadap administrasi kegiatan Bank Sampah Cawang Hijau RW 06, Kelurahan Cawang.

\section{METODE PELAKSANAAN}

Dalam rangka kegiatan Pengabdian Kepada Masyarakat (PKM) Green Action ke-19, oleh Fakultas Teknik bersama dengan Program Studi Magister Arsitek dan Program Studi Magister Manajemen UKI, salah satu kegiatannya adalah evaluasi terhadap administrasi kegiatan Bank Sampah Cawang Hijau RW 06, Kelurahan Cawang. Evaluasi dilakukan melalui wawancara terhadap pengurus dan dengan memperhatikan pembukuan yang dilakukan dalam kegiatan bank sampah Cawang Hijau RW 06, Kelurahan Cawang.

\section{HASIL DAN PEMBAHASAN}

Hasil evaluasi dan wawancara dengan pengurus bank sampah, terungkap bahwa system administrasi yang dilakukan oleh kelompok Bank Sampah Cawang Hijau Indah RW 06, belum tertata dengan rapi. Terdapat dua jenis Buku Bank Sampah yang digunakan, yaitu buku bank sampah yang merupakan sumbangan dari PT
Unilever dan sumbangan dari Suku Dinas Lingkungan Hidup Kota Administrasi Jakarta Timur, seperti ditunjukkan pada Gambar 2.

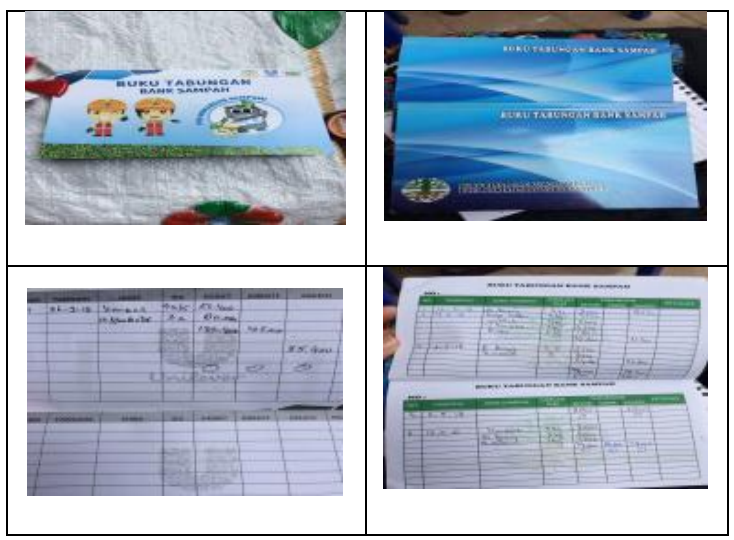

Gambar 2. Buku Tabungan Bank Sampah

Meskipun keduanya memiliki format yang sama, namun terdapat perbedaan dalam penulisan, seperti penulisan Debet/Kredit (pada buku tabungan Unilever), dan Setor/Tarik (pada buku tabungan dari Sudin Lingkungan). Kedua jenis buku bank sampah digunakan secara bersamaan untuk nasabah yang berbeda.

Penggunaan dua jenis buku tabungan menimbulkan kesalahan dalam pencatatan. Kesalahan pencatatan muncul pada penggunaan buku tabungan PT Unilever. Sejatinya, setoran dalam buku tabungan dicatatkan sebagai 'kredit', sedangkan penarikan dicatatkan sebagai 'debet'. Namun, dalam pelaksanaan di lapangan ditemukan cara pencatatan 
yang masih salah, yaitu setoran dicatatkan sebagai 'debet' dan penarikan dicatatkan sebagai 'kredit.'

Dalam buku tabungan bank sampah terekam bahwa tidak semua nasabah aktif melakukan setoran dalam setiap kegiatan yang dilakukan seminggu satu kali. Selain itu, nasabah yang menyetor, sebagian langsung mengambil uang dalam bentuk tunai, sehingga saldo tabungan menjadi nol.

Dalam kegiatan penimbangan sampah yang dijual oleh masyarakat, selain mencatat dalam buku tabungan, pengurus juga mencatatkan setoran nasabah dalam buku besar setoran, yang dicatatkan berdasarkan nama nasabah yang menyetor dan jenis barang dan beratnya, seperti ditunjukkan pada Lampiran 5a. Selanjutnya nilai rupiah dari tiap nasabah yang menyetor dicatatkan dalam Buku Besar Tabungan Nasabah, seperti terlihat pada Gambar 3.

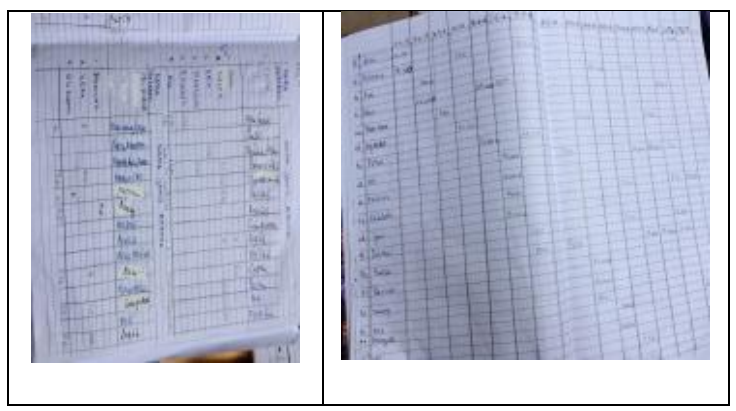

Gambar 3. Buku Besar Tabungan Nasabah
Kegiatan penimbangan mingguan dan rekap bulanan dicatatkan pada buku catatan tersendiri seperti ditunjukkan pada Gambar 4.

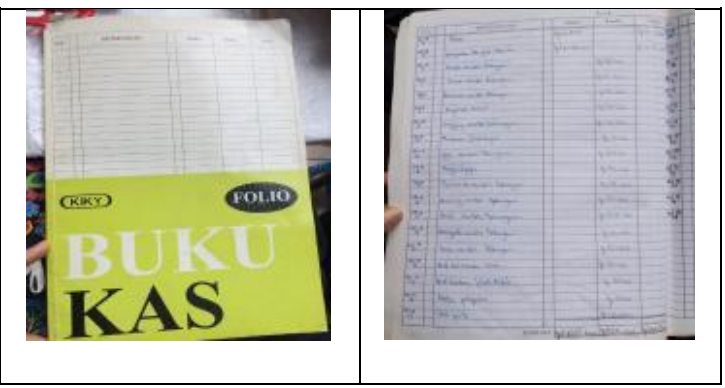

Gambar 4. Buku Kas Bank Sampah

Banyaknya catatan (dalam hal ini berjumlah empat catatan) dalam kegiatan penimbangan dapat menimbulkan kesulitan bagi pengurus. Sedangkan sebagai pengurus tidak ada imbalan khusus, tetapi merupakan kegiatan sosial. Selanjutnya, pencatatan pemasukan dan pengeluaran dicatatkan dalam Buku Kas. Pengurus hanya mencatatkan pemasukan nilai setoran nasabah yang tidak diambil pada saat penyetoran. Tidak semua nasabah bank sampah menyimpan uang penjualan sampahnya di pengurus. Sebagian nasabah yang menyetor sampah langsung menariknya dalam bentuk uang tunai. Jika uang yang ada dalam kas tidak mencukupi karena sampah yang terkumpul sebelumnya belum terjual, maka pengurus menalanginya dengan menggunakan uang pribadi. 
Kondisi tersebut menyulitkan pengurus dalam melakukan pencatatan, sehingga buku kas lebih banyak berisi pencatatan pengeluaran. seperti pengambilan tabungan oleh nasabah A, B, dst., dan/atau pengeluaran pengurus untuk pembelian barang $X, Y$, dst. Pencatatan Buku Kas seperti demikian dapat menyulitkan pengurus. Selain itu, data pencatatan pengeluaran tiap nasabah dan saldonya menjadi sulit diketahui. Juga ditemukan, pada pencatatan Buku Kas yang masih salah, yaitu pengeluaran dicatatkan dalam kolom 'Kredit', seharusnya dalam kolom 'Debet.'

Berdasarkan hasil evaluasi, maka penulis memberikan saran, bahwa Manajemen akuntansi organisasi Bank Sampah sebaiknya mengikuti aturanaturan akuntansi sederhana dengan beberapa modifikasi sesuai dengan kondisi dan kebutuhan organisasi. Mengingat, tugas pengurus dalam kegiatan bank sampah lebih bersifat sosial, maka pencatatan administrasi perlu dibuat sesederhana mungkin sehingga mudah dilakukan. Beberapa hal yang menjadi saran dalam administrasi agar kegiatan bank sampah RW 06 dapat berjalan efektif adalah:

\section{Prinsip Tabungan}

Kegiatan Bank Sampah sejatinya sama dengan prinsip menabung di bank, dalam hal ini menabung 'sampah' yang dikonversi nilainya dalam bentuk nilai rupiah. Oleh karena itu, sejatinya tidak ada pembayaran tunai atas setoran sampah dalam tiap kegiatan. Sehingga tidak ada penggunaan uang pribadi dalam kegiatan tersebut. Buku Tabungan mencatatkan setoran sampah dan nilainya dan diakumulasikan sampai periode tertentu, sesuai kesepakatan. Misalnya, dikumpulkan untuk kegiatan jalan bersama, atau untuk kebutuhan hari raya, dsb. Atau tabungan tersebut diberikan kepada nasabah menjelang hari raya. Prinsip menabung untuk suatu kegiatan tertentu akan membuat kegiatan bank sampah menjadi lebih bergairah, karena ada kegiatan besar tertentu yang dapat diharapkan dari kegiatan bank sampah. Dengan prinsip yang tepat, pencatatan kegiatan bank sampah akan menjadi lebih baik. (Catatan.: Jika 'terpaksa' harus dilakukan setoran sampah dengan pembayaran tunai, maka setoran tersebut tidak dicatatkan dalam buku tabungan, karena cara tersebut bukan termasuk kegiatan menabung). 


\section{Prinsip Pencatatan Kegiatan Bank Sampah \\ a. Pencatatan Buku Tabungan}

Buku tabungan bank sampah RT 06 menggunakan buku sumbangan dari Sudin, dan buku tabungan sumbangan PT. Unilever. Untuk itu penulisan/pencatatan setoran dan penarikan harus dilakukan dengan benar dan konsisten. Menurut prinsip akuntansi, pencatatan 'Setoran' ditulis dalam kolom 'Kredit'. Saran lain terkait buku tabungan: jenis barang yang disetor tidak perlu dicatatkan, karena dengan pencatatan secara manual, pengurus bank sampah harus mencatatkan jenis barang tersebut sebanyak dua kali, yaitu dalam Buku Tabungan bank sampah dan dalam Buku Besar. Hal itu menjadi tidak efisien. Pencatatan jenis barang yang disetor oleh nasabah, cukup ditulis dalam Buku Besar. Selain itu, bagi nasabah yang menyetorkan sampahnya, cukup dicatatkan nilai rupiahnya dalam kolom 'Kredit/Setor' pada buku tabungan Bank Sampah. Jika nasabah ingin mengetahui jenis barang, berat, dan nilai barang yang disetor dapat melihat pada Buku Besar yang ada di pengurus. Dengan demikian, pencatatan menjadi lebih mudah, efektif, dan efisien. Pencatatan dalam Buku tabungan bank sampah yang tepat adalah seperti contoh pada Tabel 1.

Tabel 1. Pencatatan Bank Sampah

No \begin{tabular}{ccccc} 
Tgl & $\begin{array}{c}\text { Jenis } \\
\text { Brg* }^{*}\end{array}$ & $\begin{array}{l}\text { Kredit/ } \\
\text { Setor }\end{array}$ & $\begin{array}{l}\text { Debet/ } \\
\text { Tarik }\end{array}$ & Saldo \\
\hline
\end{tabular}

\section{b. Pencatatan Jurnal Harian}

Pencatatan Rekap penimbangan yang dilakukan oleh pengurus dicatatkan sebagai Jurnal Harian, yang mencatat kegiatan penerimaan setoran dari nasabah. Untuk membuat pencatatan kegiatan bank sampah yang efisien, diusulkan pencatatan Jurnal Harian sebagai rekap penimbangan juga sekaligus sebagai pencatatan Buku Besar, yang mencatatkan penjualan yang dilakukan oleh pengurus kepada pengepul, dalam hal ini Sudin Kelurahan Cawang. Diusulkan pencatatan Jurnal Harian/Buku Besar Bank Sampah seperti dijelaskan pada Tabel 2.

Dari Buku Besar tersebut selanjutnya dapat dibuat Laporan Bulanan/Tahunan kegiatan penyetoran sampah dan penjualannya, yaitu baris Total Penerimaan dan Total Penjualan tiap bulan/tengah tahun/akhir tahun.

\section{c. Pencatatan Buku Kas/Neraca Saldo}


Pencatatan Buku Kas sekaligus berfungsi sebagai Neraca Saldo Bank Sampah, sejatinya menjelaskan kegiatan bank sampah, yaitu Pemasukan, Pengeluaran dan Saldo dalam nilai rupiah. Penerimaan Kas berupa hasil penjualan sampah yang disetor oleh nasabah, dan dicatatkan dalam kolom 'Kredit'. Sedangkan pengambilan dana oleh nasabah (sebaiknya 'hanya jika terpaksa' dan dalam jumlah yang dibatasi), dan berbagai pengeluaran oleh pengurus (yang telah disepakati), ditulis dalam kolom 'Debet'. Selanjutnya dalam kolom 'Saldo' tercantum dana total yang dimiliki oleh Kelompok Bank Sampah Cawang Hijau Indah, yang merupakan dana nasabah ditambah keuntungan penjualan dikurangi pengeluaran pengurus.

Pencatatan Buku Kas/Neraca Saldo sebaiknya diumumkan setiap bulan, dan ditanda -tangan oleh semua pengurus dan wakil anggota (lihat Tabel 3).

Tabel 2. Buku Besar Bank Sampah

\begin{tabular}{|c|c|c|c|c|c|c|c|c|c|c|}
\hline \multirow{2}{*}{ Tanggal } & \multirow{2}{*}{$\begin{array}{l}\text { Nama } \\
\text { Nasabah }\end{array}$} & \multicolumn{2}{|c|}{ Jenis A } & \multicolumn{2}{|c|}{ Jenis B } & \multicolumn{2}{|c|}{ Jenis C } & \multirow{2}{*}{$\begin{array}{l}d s t \\
\ldots\end{array}$} & \multirow{2}{*}{$\begin{array}{l}\text { TOTAL } \\
\text { BERAT (KG) }\end{array}$} & \multirow{2}{*}{$\begin{array}{l}\text { TOTAL } \\
\text { RUPIAH (RP) }\end{array}$} \\
\hline & & $\mathrm{Kg}$ & $\mathrm{Rp}$ & $\mathrm{Kg}$ & $\mathrm{Rp}$ & $\mathrm{Kg}$ & $\mathrm{Rp}$ & & & \\
\hline \multirow{5}{*}{$1 / 1 / 19$} & A & & & & & & & & & \\
\hline & $B$ & & & & & & & & & \\
\hline & C & & & & & & & & & \\
\hline & $\begin{array}{l}\text { TOTAL } \\
\text { PENERIMAAN }\end{array}$ & & & & & & & & & \\
\hline & $\begin{array}{l}\text { TOTAL } \\
\text { PENJUALAN }\end{array}$ & & & & & & & & & \\
\hline
\end{tabular}

Tabel 3. Buku Kas Bank Sampah

\begin{tabular}{|c|c|c|c|c|c|c|c|}
\hline Tanggal & Keterangan & Debet & Kredit & Saldo & $\begin{array}{c}\text { Ttd } \\
\text { Bendahara }\end{array}$ & Ttd Ketua & $\begin{array}{c}\text { Ttd } \\
\text { Anggota }\end{array}$ \\
\hline $1 / 1 / 19$ & $\begin{array}{l}\text { TOTAL } \\
\text { PENERIMAAN }\end{array}$ & & & V & & & \\
\hline $8 / 1 / 19$ & $\begin{array}{l}\text { TOTAL } \\
\text { PENJUALAN }\end{array}$ & & V & V & & & \\
\hline & $\begin{array}{l}\text { PENGELUARAN: } \\
\text { a. pengeluaran } x \\
\text { b. pengeluaran } y \\
\text { c. } \ldots\end{array}$ & $\begin{array}{l}\text { V } \\
\text { V } \\
\text { V }\end{array}$ & & $\begin{array}{l}\text { V } \\
\text { V } \\
\text { Vy) }\end{array}$ & & & \\
\hline $15 / 1 / 19$ & SALDO KAS $\left.{ }^{* \star}\right)$ & & & $V^{z)}$ & $\left.{ }^{* \star}\right)$ & $\left.{ }^{* \star}\right)$ & $\left.{ }^{* \star}\right)$ \\
\hline
\end{tabular}




\section{SIMPULAN}

Dengan prinsip tabungan bank sampah yang tepat dan disepakati bersama, serta dengan sistem pendataan yang sederhana, mudah, dan transparan, maka kegiatan Bank Sampah Cawang Hijau Indah RW 06 diharapkan dapat berkesinambungan.

\section{UCAPAN TERIMA KASIH}

Ucapan terima kasih penulis sampaikan kepada Fakultas Teknik UKI, yang melibatkan dosen bidang ekonomi dan LPPM UKI.

\section{REFERENSI}

Dwiyatmo Kus. (2007). Pengantar Pendidikan Lingkungan Hidup. Yogyakarta: GAVA MEDIA.

Furnanda, R. (2012). Partisipasi lbu Rumah Tangga dalam Mewujudkan Program

https://www.harmony.co.id/blog/konsepdasar-manajemen-keuangan Diakses tanggal 21 April 2021.
Medan Green dan Clean (MdGC) melalui Pengelolaan Bank Sampah di Lingkungan II Kelurahan Tanjung Gusta Kecamatan Medan Helvetia Kota Medan. Universitas Sumatera Utara.

Hardin, G.J. (1982). The Tragedy of the Commons in Environmental Economics. US: Environmental Fund.

Wulandari (2014). Evaluasi Prospek Keberlanjutan Pengelolaan Sampah di Bank Sampah Studi Kasus Bank Sampah di Kota Makassar. Yogyakarta. Universitas Gadjah Mada. https://www.jurnal.id/id/blog/cara-mudahmembuat-laporan-keuangansederhana-bagi-ukm/ Diakses tanggal 15 September 2018.

https://dlh.bulelengkab.go.id/informasi/detail/ artikel/apa-itu-bank-sampah-26 Diakses April 2020

https://dlh.bulelengkab.go.id/informasi/detail/ artikel/apa-itu-bank-sampah-26 Diakses April 2020 